\title{
Using Microwave as a Decontaminated Equipment for Frozen Sheep Meats
}

\author{
Nadia Ibrahim Abdul aali, Dahfer Abed Ali Alobaidi \\ Department of Public Health / College of Veterinary Medicine / University of Baghdad
}

\begin{abstract}
This study was carried out at the college of veterinary medicine, University of Baghdad, for three months, the aim of the present study was to investigate the effect of different times of microwave oven on the freezing sheep meat to reduced limited of bacteria on meat, Exposure three periods of microwave (10,15 and 20) seconds. The data obtained revealed the following results: were significant differences $(P<0.05)$ between the means of bacterial count before exposure of microwave were limited of ranges $(5.30-5.51)$ log cfu/g meat and total coliform were ranges (1.88 - 2.04) log cfu/g meat. The third times of exposure of microwave(25) seconds were significant difference $(p<0.05)$ between the data count, were reduced total of bacterial count for above 1.2 log were range $(4.06-4.17)$ $\log \mathrm{cfu} / \mathrm{g}$ meat and total coliform were range $(0.27-0.62) \mathrm{log}$ cfu $/ \mathrm{g}$ meat.
\end{abstract}

Keywords: Microwave, frozen sheep meat, Total bacterial count

\section{Introduction}

The microwave oven is one of the great inventions of the 20th century; over $90 \%$ of homes in America have at least one. Microwave ovens can play an important role at mealtime, but special care must be taken when cooking or reheating meat, poultry, fish, and eggs to make sure they are prepared safely $(1 ; 2)$. Microwave ovens can cook unevenly and leave "cold spots" where harmful bacteria can survive. For this reason, it is important to use a food thermometer and test food in several places to be sure it has reached the recommended safe temperature to destroy bacteria and other pathogens that could cause food borne illness. Bacteria will be destroyed during microwave cooking just as in other types of ovens, so food is safe cooked in a microwave oven. However, the food can cook less evenly than in a conventional oven. Microwave cooking can be uneven just as with frying and grilling.

Microwaves refer to the electromagnetic waves in the frequency range of 300 to 300,000 megahertz $(3 ; 4)$. The use of microwave oven provides a convenient way to thaw, cook and reheat foods.

Microwave relies on the same heating principle as radiofrequency heating but it uses higher frequencies. The permitted frequency bands for microwave are 433, 915, 2,450 and $5,800 \mathrm{MHz}$, as specified by the US FCC. Therefore, microwave at $915 \mathrm{MHz}$ is more suitable for heating thick masses of materials such as red meats $(5 ; 6)$. Microwave has previously been studied for its effectiveness in destroying bacteria and extending the shelf life of meat products $(7 ; 8 ; 9 ; 10)$. It was found that bacterial counts were reduced by $1-2 \log \mathrm{cfu} / \mathrm{g}$ in beef samples after exposure to microwave for 20-30 seconds. Heating by MW energy is used for several purposes, e.g., cooking, pasteurization, sterilization and blanching of foods $(11 ; 12 ; 13 ; 14)$.

The short time of exposure of heat microwave were best for meat toreduce of bacteria ranges of times from $(20-30)$ seconds, total bacterial count $(14 ; 15)$. heated in a microwave oven, bacterial counts were reduced by $1 \log$ cycle in $20 \mathrm{~s}$ and by $2 \log$ cycles in $30 \mathrm{~s}$ exposure $(16 ; 17)$.

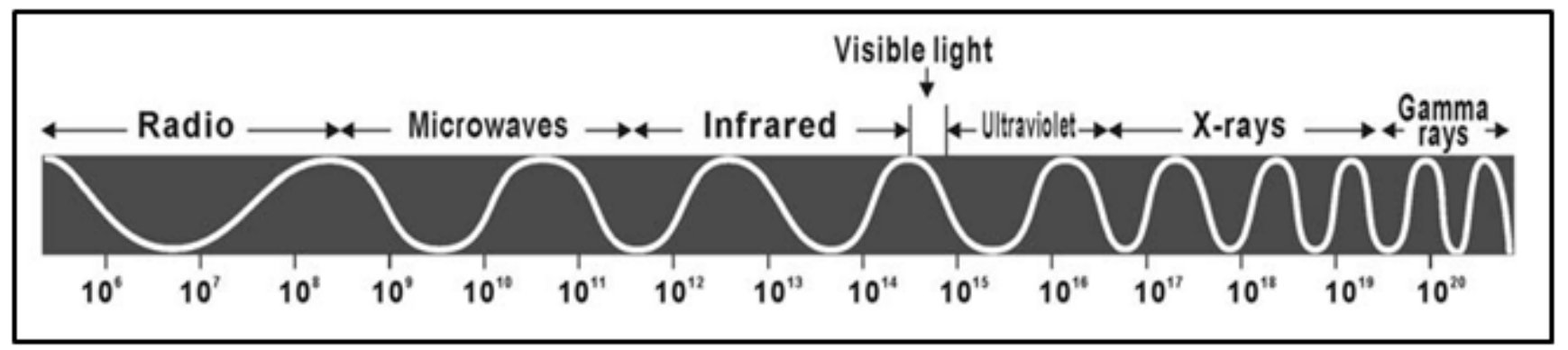

Frequency $(\mathrm{Hz})$

Figure 1: Electromagnetic waves spectrum. Resource $(3 ; 4)$

\section{Material \& Methods}

\section{Collection of meat samples:}

The sample of meat was from imported frozen sheep meat. Collected from local super market. Number of samples fiftysix sample (was means 10X 3 frequency). Storage the samples in the laboratory, in the freezer (18-) $\mathrm{c}^{\circ}$, before beginning the bacteriological test.

\section{Microwave irradiation:}

A home microwave oven $2450 \mathrm{MHz}-900 \mathrm{~W}$, Kelvinator (model 1.5CU, FT), different times of radiation $(10,15$ and $25 \mathrm{sec})$ 


\section{International Journal of Science and Research (IJSR) \\ ISSN (Online): 2319-7064 \\ Index Copernicus Value (2015): 78.96 | Impact Factor (2015): 6.391}

Dilution of samples for bacteriological test

Made the serial dilutions firstly, from initial $10^{1}$ to $10^{6}$, the bottle dilutions Content peptone water $(1 \%) 90 \mathrm{ml}$ and other bottles content peptone water $9 \mathrm{ml}$ this bottles dilution sterilization in autoclave $121 \mathrm{C}^{\circ}$ for 15 minutes.add 10 grams from meat samples to first bottle dilute content $90 \mathrm{ml}$ peptone water to make $10^{1}$ then tacked $1 \mathrm{ml}$ to second bottle to made $10^{2}$ and then made other dilutions to $10^{-6}$.

\section{Bacteriological tests}

Total bacterial count or total plate count (T.P.C.) described from (19), after made the dilutions add $1 \mathrm{ml}$ from bottle dilution $10^{1}$ to multiple Petri dish content media culture (nutrient agar) and $1 \mathrm{ml}$ from other dilutions to multiple petri dish, then incubate at $37 \mathrm{C}^{\circ}$ for overnight (24 Hour), then count the colony of culture of bacteria ranges $(30-300)$ : -

\section{Count of bacteria $(\mathrm{CFU}) / \mathrm{gr}$ meat $=$ mean colony culture $\mathrm{X}$ dilute factor $^{-1}$}

Total coliform count: described from (19), Petri dish content media culture(VRBA) violet red bile agar and $1 \mathrm{ml}$ from other dilutions to multiple petri dish, then incubate at $37 \mathrm{C}^{\circ}$ for overnight (24 Hour), then count the colony of culture of bacteria ranges $(15-150)$ : -

Total coli form $\operatorname{count}(\mathrm{CFU}) / \mathrm{gr}$ meat $=$ mean colony culture $\mathrm{X}$ dilute factor $^{-1}$

\section{Statistical Analysis}

The results were analyzed statistically, determining using completely randomized design (CRD). The significance of differences between groups was verified by the Duncan multiple range test; Levels of significance non-significant (ns), $\mathrm{p}<0.05$, using SAS program (20).

\section{RESULTS \& DISCUSSION}

Table (1) shows the total bacterial load of untreated with microwave and treated with microwave in frozen sheep meat at $-18^{\circ} \mathrm{C}$ exposure short times for $0,15,20$ and 25 seconds. The means of total bacterial counts were significant difference $(p<0.05)$ between the data before exposure of microwave were range $(5.30-5.51) \mathrm{cfu} / \mathrm{g}$ meat. The total bacterial counts decreased with the increase of the microwave -irradiation from 10,15 and 25 seconds. The means of total bacterial count at the 10 and 15 seconds of exposure to microwave were range $(5.08-5.39) \mathrm{cfu} / \mathrm{g}$ meat and $(5.10-5.50)$, the decrease of bacterial count was a little of the total bacterial count compare with total bacterial count before exposure.the means of total bacterial count at the 25 seconds of exposure to microwave were range $(4.06-4.17)$ $\mathrm{cfu} / \mathrm{g}$ meat, were reduced the bacterial count to $1.20 \log$ of bacteria.

The mean values of total aerobic bacterial counts that mentioned in Table 1, were similar to the results obtained by the other researchers for exposure of the frozen meat (9;10; and 12).when heated in a microwave oven, bacterial counts were reduced by 1 log cycle in 20 s.

Table (2) shows the total coliform of untreated with microwave and treated with microwave in frozen sheep meat at $-18^{\circ} \mathrm{C}$ exposure short times for $0,15,20$ and 25 seconds. The means of total coliform counts were significant difference $(p<0.05)$ between the data before exposure of microwave were range $(1.88-2.04) \mathrm{cfu} / \mathrm{g}$ meat. The total coliform counts decreased with the increase of the microwave -irradiation from 10,15 and 25 seconds. The means of total coliform count at the 10 and 15 seconds of exposure to microwave were range $(1.67-1.95) \mathrm{cfu} / \mathrm{g}$ meat and $(1.45-1.80)$, the decrease of bacterial count was a little of the total coliform count compare with total coliform count before exposure. the means of total coliform count at the 25 seconds of exposure to microwave were range $(0.28-0.62)$ $\mathrm{cfu} / \mathrm{g}$ meat, were reduced the bacterial count to $1.20 \mathrm{log}$ of bacteria.

The mean values of total coliform counts that mentioned in Table 2, were similar to the results obtained by the other researchers for exposure of the frozen meat (13;14; and 15).

An overall conclusion on the basis of this investigation pointed out that the microwave -irradiation from 10,15 seconds not good to reduce the bacterial counts in the frozen sheep meats $(17 ; 18)$.

The mean values of total aerobic bacterial counts and total coliform counts that mentioned in Table 1,2 and were similar to the results obtained by the other researchers for the microwave -irradiation at 25 seconds the frozen sheepmeat $(9 ; 10 ; 11$ and 12). the microwave -irradiation 25 seconds was the best exposure of irradiation to reduce the mean values of total aerobic bacterial counts and total coliform counts (table1;2).

Table 1: Means of bacterial count(cfu)/gm meat before exposure of microwave and after exposure of different times of microwaves oven $(0,15,20$ and 25$)$ seconds

\begin{tabular}{|c|c|c|c|c|}
\hline \multirow{2}{*}{$\begin{array}{c}\text { Origin } \\
\text { (Frequency) }\end{array}$} & $\begin{array}{c}\text { Means of bacterial count(cfu)/gm meat } \\
\text { before exposure of microwave }\end{array}$ & \multicolumn{4}{|l|}{ Means of bacterial count after exposure of different times of microwaves oven } \\
\cline { 3 - 5 } & & 10 seconds $/$ gm meat & 25 seconds \\
\hline Australia (6) & $5.30^{\mathrm{A}} \pm 0.07$ & $5.34^{\mathrm{A}} \pm 0.08$ & $5.09^{\mathrm{B}} \pm 0.05$ & $4.06^{\mathrm{C}} \pm 0.04$ \\
\hline New Zealand (6) & $5.32^{\mathrm{A}} \pm 0.06$ & $5.23^{\mathrm{AB}} \pm 0.06$ & $5.08^{\mathrm{B}} \pm 0.04$ & $4.06^{\mathrm{C}} \pm 0.04$ \\
\hline UAE (3) & $5.51^{\mathrm{A}} \pm 0.04$ & $5.39^{\mathrm{AB}} \pm 0.05$ & $5.28^{\mathrm{B}} \pm 0.06$ & $4.17^{\mathrm{C}} \pm 0.07$ \\
\hline Moldavia (3) & $5.48^{\mathrm{A}} \pm 0.03$ & $5.37^{\mathrm{AB}} \pm 0.04$ & $5.26^{\mathrm{B}} \pm 0.04$ & $4.14^{\mathrm{bc}} \pm 0.05$ \\
\hline Significant & $\mathrm{P}<0.05$ & $\mathrm{P}<0.05$ & $\mathrm{P}<0.05$ & $\mathrm{P}<0.05$ \\
\hline
\end{tabular}




\section{International Journal of Science and Research (IJSR) \\ ISSN (Online): 2319-7064 \\ Index Copernicus Value (2015): 78.96 | Impact Factor (2015): 6.391}

Table 2: Means of Total coliform count before exposure of microwave and after exposure of different times of microwaves oven $(0,15,20$ and 25$)$ seconds

\begin{tabular}{|c|c|c|c|c|}
\hline \multirow{2}{*}{$\begin{array}{c}\text { Origin } \\
\text { Frequency) }\end{array}$} & $\begin{array}{c}\text { Means of total coliform } \\
\text { count(cfu)/gm meat before } \\
\text { exposure of microwave }\end{array}$ & \multicolumn{2}{|c|}{$\begin{array}{c}\text { Means of Total coliform count after exposure of different times of } \\
\text { microwaves oven (cfu)/gm meat }\end{array}$} \\
\cline { 2 - 5 } & & 10 seconds & 15 seconds & 20 seconds \\
\hline Australia (6) & $1.90^{\mathrm{A}} \pm 0.06 \mathrm{~b}$ & $1.73^{\mathrm{A}} \pm 0.09 \mathrm{~b}$ & $1.45^{\mathrm{C}} \pm 0.07 \mathrm{~b}$ & $0.47^{\mathrm{D}} \pm 0.09 \mathrm{~b}$ \\
\hline New Zealand (6) & $1.91^{\mathrm{A}} \pm 0.01 \mathrm{ab}$ & $1.71^{\mathrm{B}} \pm 0.01 \mathrm{~b}$ & $1.46^{\mathrm{C}} \pm 0.1 \mathrm{~b}$ & $0.27^{\mathrm{D}} \pm 0.03 \mathrm{c}$ \\
\hline Moldavia (3) & $2.04^{\mathrm{A}} \pm 0.05 \mathrm{a}$ & $1.95^{\mathrm{A}} \pm 0.01 \mathrm{a}$ & $1.80^{\mathrm{A}} \pm 0.04 \mathrm{a}$ & $0.62^{\mathrm{C}} \pm 0.05 \mathrm{a}$ \\
\hline UAE (3) & $1.88^{\mathrm{A}} \pm 0.03 \mathrm{~b}$ & $1.67^{\mathrm{B}} \pm 0.03$ & $1.47^{\mathrm{C}} \pm 0.02 \mathrm{~b}$ & $0.28^{\mathrm{D}} \pm 0.02 \mathrm{c}$ \\
\hline Significant & $\mathrm{P}<0.05$ & $\mathrm{P}<0.05$ & $\mathrm{P}<0.05$ & $\mathrm{P}<0.05$ \\
\hline
\end{tabular}

\section{References}

[1] FSIS.Food Safety and Inspection Service.(2011). Microwave Ovens and Food Safety. www.fsis.usda.gov

[2] U.S. Food and Drug Administration.2000. Center for devices and radiological Health. Microwave oven radiation. [cited 04 Aug 17] Available from: URL: http://www.fda.gov/cdrh/consumer/microwave.html

[3] Yilmaz, I., Arici, M. \& Gümüs, T. (2005). Changes of microbiological quality in meatballs after heat treatment. European Food Research and Technology 221: 281-283.

[4] Lau MH, Tang J (2002). Pasteurization of pickled asparagus using $915 \mathrm{MHz}$ microwaves. J. Food Eng. 51:283-290.

[5] Yarmand, M., S., Homayouni, A. (2011) Microwave processing of meat. In: Microwave Heating (Ed: Chandra, U.) InTech, Rujeka, pp 107-134. http://www.intechopen.com/books/microwaveheating/microwave-processing-of-meat

[6] Aziz, H. N., Mahrous, S. R., Youssef, B. M. (2002) Effect of gamma-ray and microwave treatment on the shelf-life of beef products stored at $5^{\circ} \mathrm{C}$. Food Control13: 437-444.

[7] Farag , R.S. Daw ,Z.Y.,Mahmoud ,E.A.and ABD ElWahab S.A. (2001). A comparison of g-irradiation and microwave treatments on the lipids and microbiological pattern of beef liver.Grasas y Aceites 45.Vol. 52. Fasc $.1,45-51$.

[8] Midgley,J. ,Alison,S.( 2006).Review of new and emerging technologies for red meat Safety.Meat \& Livestock Australia Limited ABN 39081678364. (MLA).

[9] Shenga E., Singh, R.P., Yadav A.S. (2010). Effect of pasteurization of shell egg on its qualitycharacteristics under ambient storage. J. Food Sci. Technol., 47: 420425.

[10] Kaszewska, J.B., Krzysztof, S., Zbigniew P., Zbigniew, D., Mścisław,S.(2014) Effect of microwave radiation on microorganisms in fish meals .Ann. Anim. Sci., Vol. 14, No. 3 : 623-636.

[11] YilmazS., F., Yetimand H.,Ockerman, W.(2002) The effect of different cooking procedures on microbiologicaland chemical quality characteristics of Tekirdag meatballs.NahrungFood . No. 4, pp. 276-278.

[12] Tochampa, W., Jittrepotch, N., Kongbangkerd, T., Kraboun, K. andRojsuntornkitti, K.(2011). The study of microwave heating time on chemical and microbiologicalproperties and sensory evaluation in sweet fermented glutinous rice(Khao-Mark). Inter. F. Res. J.18: 239-248.
[13]Krifi, B.,Mosbah,A., and Jaafar ,M.( 2014). Microbiological comparison of microwave and traditional thawing processes for poultry meat. African J. of Micro.Res. Vol. 8(1), pp. 109-117. http://www.academicjournals.org/AJMR

[14] Lihan H.,Joseph S. (2010).New Automated Microwave Heating Process for Cooking and pasteurization of microwaveable foods containing raw meats.J.of F. Sci. Vol :75, (2); 110- 115.

[15] Sood, P., Neeru S., and Trupti, G. (2015). Microwaves: An Alternative bacterial sterilization technique.J.bio.sci. Vol.3 No.2; $1-5$.

[16] Apostolo I., Papadopouloua C., Levidiotoua S., Ioannides k. (2005). The effect of short-time microwave exposures on Escherichia coli O157:H7 inoculated onto chicken meat portions and whole chickens. Int. J. Food Microbiol. 101:105-110.

[17] Jamshidi,A., Seifi ,H.A., Kooshan ,M.(2010).The effect of short-time microwave exposures on Escherichia coli O157:H7 inoculated onto beef slices.African J. of Micro. Res. Vol. 4, No;22 :23712374.http://www.academicjournals.org/ajmr

[18] Jamshidi, A., Ghasemi, A. and Mohammadi, A.(2009).The effect of short-time microwave exposures on Salmonella typhimurium inoculated onto chicken drumettes.Iranian Journal of Veterinary Research, Shiraz University, Vol. 10, No. 4, Ser. No. 29.378- 382.

[19] Talab, A.S. 2014.Effect of Cooking Methods and Freezing Storage on the Quality Characteristics of Fish Cutlets. Journal of Food Science and Technology 6(4): 468-479.

[20]BAM. Bacteriological analytical Manual, $8^{\text {th }}$ Edition , Revision A ,( 1998).Chapter 12. http://www.fda.gov/food/science

[21] SAS. User's guide release 6.03. EditionSAS institute.)2011(. Inc.Cory. NC. 